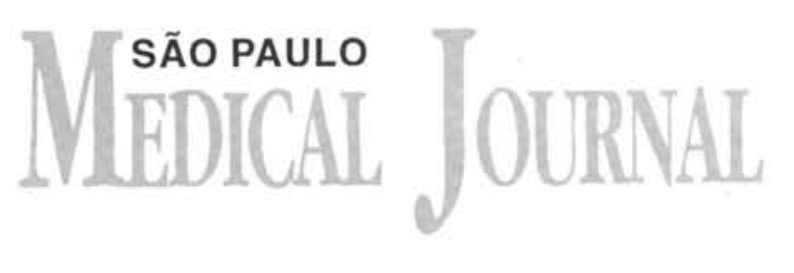

Ricardo Edésio Amorim Santos Diniz, José Goldenberg, José Carlos Medina de Carvalho, Carlos Eduardo Sales

Gomes, Evelin Diana Goldenberg, Angelo Sementille

\title{
Lymphoma of unknown origin located in paravertebral muscles: an unusual cause of low back pain in children
}

The authors report a case of an adolescent with a poorly differentiated lymphoma of unknown origin located at paravertebral muscles, whose presenty symptom was low back pain.

UNITERMS: Lymphoma. Back pain.

\section{INTRODUCTION}

$\mathrm{L}$ ow back pain in children and adolescents is an unusual symptom. It is rarely of a psychogenic nature and its cause is usually identified. Etiology may be infective, inflammatory, traumatic, developmental disorders, disc pathology or neoplasic disease $(7,8,14,16)$.

Neoplasic causes of lumbar pain in childhood may be benign (osteoid osteoma, benign osteoblastoma, aneurysmal bone cyst, eosinophilic granuloma); malignant primary tumors (Ewings sarcoma, osteogenic sarcoma); metastatic tumors (neuroblastoma, Wilms tumor); leukemia or spinal cord tumors (gliomas, dermoid cysts, lipoma, intramedullary cyst) (16).

Non-Hodgkin's lymphomas represent 7 to $10 \%$ of the malignant tumors in the first and second decades of life (9), and are one of the main malignancies in childhood, surpassed only by leukemia and central nervous system tumors (17). Involvement of skeletal musculature is very

\section{Address for correspondence:}

Ricardo Edésio Amorim Santos Diniz

Hospital Ana Costa de Santos

Universidade Federal de São Paulo

Disciplina de Reumatologia

Rua Botucatu, 740 - Vila Clementino

São Paulo - SP - Brasil - CEP 04023.062 unusual, mainly when it is the primary site which has been described in only a few cases $(5,6,10,11,13,15)$.

In this report the authors describe a poorly differentiated lymphocytic lymphoma in the paravertebral musculature of an adolescent whose presenting symptom was low back pain associated with neurologic signs of nerve root compression.

\section{CASE REPORT}

L.S.P., a 12 year old caucasian boy, with a twomonth history of continuous lumbar pain which was aggravated on standing and relieved by rest. Thirty days later the pain worsened with radiation towards the right thigh, right leg, left foot and left leg. Pain was of a burning nature and he had progressive difficulty in walking. At this stage he was admitted for examination to elucidate the diagnosis. There was no mention of fever, weight loss, sweating or local inflammatory signs.

On the examination his general condition was fair, breathing was normal, he weighed $48 \mathrm{~kg}$ and its height was $1.55 \mathrm{~cm}$; BP: $110 \times 80 \mathrm{mmHg}$. Normal cardiopulmonary auscultation. His abdomen was painless, without organomegaly or palpable masses. Peripheral 
lymphadenopathy was not observed. Pulses were present and symmetric. The patient had difficulty in walking, crural paraparesis and decreased patellar and ankle jerk reflexes. Lasegue was positive at $30^{\circ}$ on the left and $40^{\circ}$ on the right and he had generalized hypoaesthesia of the lower limbs.

Hemoglobin was $13 \mathrm{~g} / \mathrm{dl}$, WBC count was 8,000 leucocyte/ $\mathrm{mm} 3$ with normal differential distribution count and 516.000 platelet $/ \mathrm{mm} 3$. ESR was $34 \mathrm{~mm} / 1$ st hour (Westergreen). Calcium and phosphorus serum levels, alkaline phosphatase, protein electrophoresis and urinalysis were normal. Chest X-ray was normal. X-ray of the lumbosacral spine showed bony sclerosis of the left side of the L3 body which had a large transversal process and an obscure left pedicle (fig. 1). Computorized tomography (CT) (L2-S1) showed hypertrophia of the left process and vertebral body of L3 with thickening and sclerosis of left pedicle. The rachi canal was not stenosed. During surgery a mass was observed englobing the nerve root bilateraly. The initial biopsy specimen confirmed the presence of malignant neoplasm and the tumoral mass was excised. The pathologic report showed fragments of fibromuscular tissue containing solid blocks of neoplastic lymphocytic cells. The nuclei were hyperchromatic with few mitoses (fig.3), and a poorly differentiated lymphocytic lymphoma infiltrating the skeletal muscle was diagnosed. Bony fragments obtained at operation did not show invasion by tumor.

Once the diagnosis was made, the patient underwent intensive investigation in order to identify a possible primary focus including abdominal ultrasonography (US); computorized tomography of the skull, thorax, abdomen and pelvis; bone marrow biopsy (iliac crista) all of which were normal.

The patient was treated with systemic chemotherapy and local radiotherapy, and after 11 months of follow up the patient was free of any clinical manifestation of disease.

\section{DISCUSSION}

Skeletal muscle involvement by lymphoma may occur by metatastic dissemination, by direct invasion from a lymphnode or adjacent bone, or more rarely due to a primary extranodal lesion (1).

Muscular involvement with clinical or radiologic expression is not common, being found by tomography in only $5 \%$ of the 400 cases of non-Hodgkin lymphoma in the Glazer et al. series (4) and in $5.4 \%$ of the 110 cases

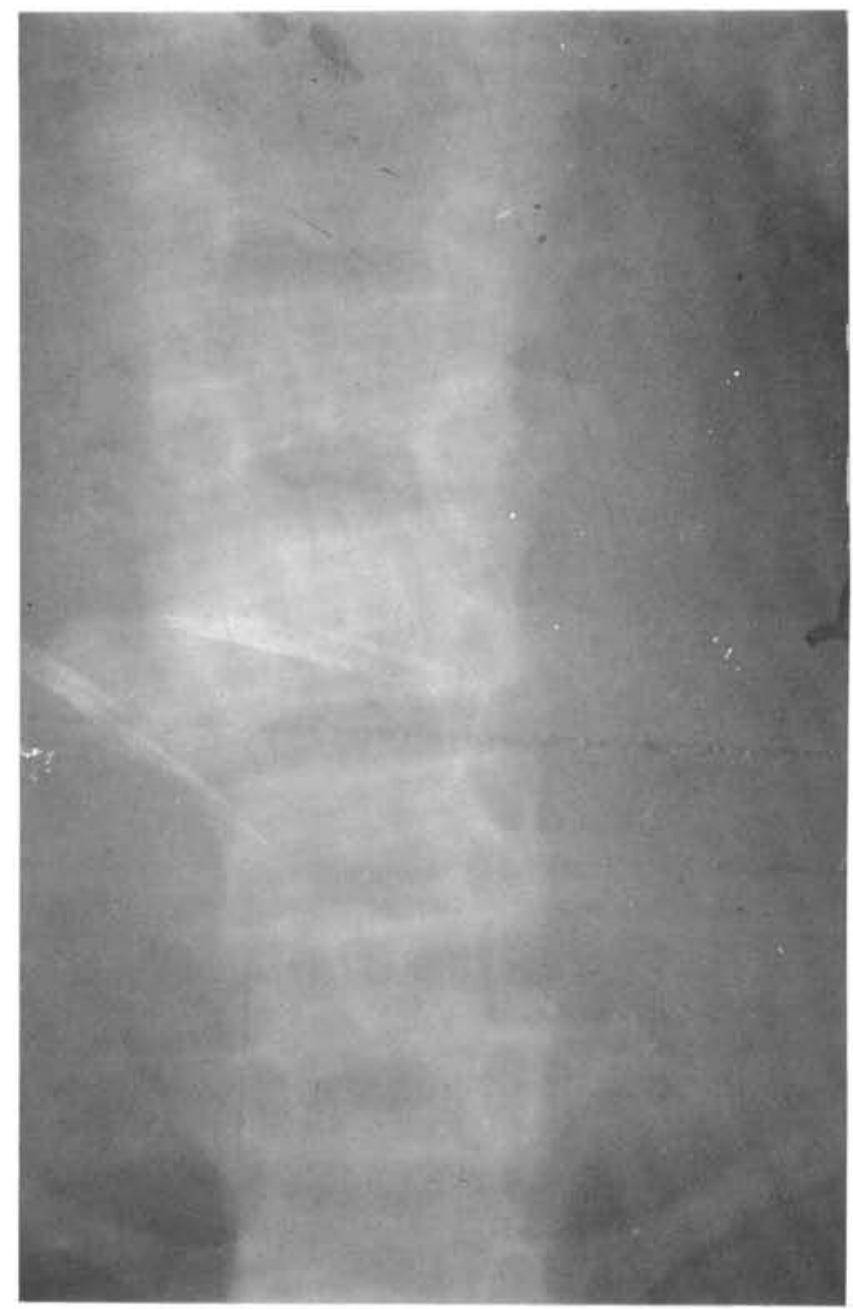

Figure 1 - X-ray of lumbar spine showing bone sclerosis of the left side of the L3 vertebral body, which had a large transversal process.

analyzed by Newal (12). However microscopic involvement can be more frequent, especially in those cases with widespread systemic disease as shown by Buerger and Monteleone (2) who noted microscopic metastatic foci in $40 \%$ of the patients who underwent multiple muscular biopsies.

On the other hand, the primary lymphoma in skeletal muscle seems to be very unusual. Freeman et al. (3) in his series of 1,467 extranodal lymphoma cases observed that only $6 \%$ had their origin in connective tissue, although they did not mention muscular involvement. Among 7,000 lymphomas seen at the Mayo Clinic during a period of 10 years Travis et al. (15) found isolated muscular involvement in only eight cases $(0.11 \%)$.

The few cases present in the literature $(5,10,11,13)$ are indicative of the rarity of this lesion, as well as the 


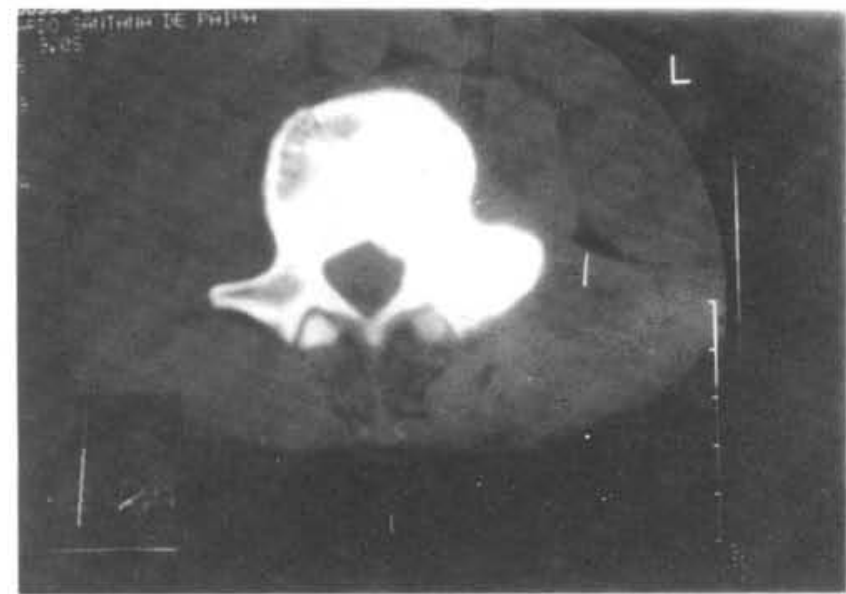

Figure 2- Computorized tomography of L3 showing hypertrophia of the left process and vertebral body, with thinckening and sclerosis of the left pedicle.

difficulty in confirming this diagnosis. Cytologic examination, electron microscopy and immunohistochemical markers are frequently needed to accurately distinguish lymphoma from others small cell tumors which can involve the muscle $(5,6)$.

In most of the reported cases of primary involvement the affected muscles are in the lower limbs $(5,6,15)$ leading to an increase of the soft tissues, due to tumor mass or edema, localized pain and rarely paresthesia.

The involvement of psoas and paravertebral musculature as observed in the present case is often related to an adjacent lymphadenopathy or to a primary bony lesion (1). However, the pathologic study of the bony specimens obtained during the surgery as well as a post-operative investigation using CT and US did not show evidence of a primary bone tumor.

Although bony involvement had been suggested by the radiological findings, this was not confirmed by the

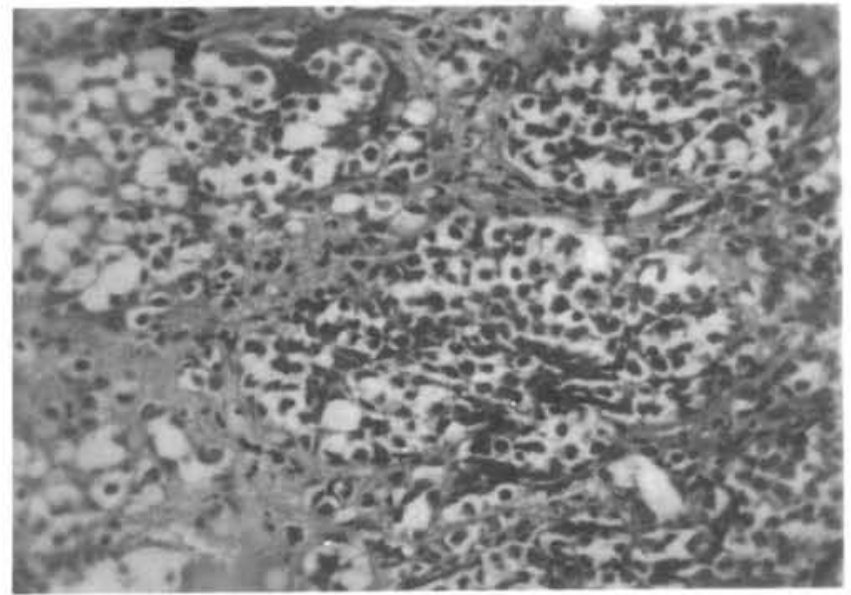

Figure 3 - Pathology. HE: fragments of fibromuscular tissue containint blocks of neoplastic lymphocytic cells.

histological study made of the pedicle and vertebral body. The observed alterations were a probably result of an increase in the local irrigation due to the adjacent neoplasm.

The finding of a primary lymphoma in skeletal muscle can be explained by three hypothesis: the tumor might have arisen from an adenopathy which was not located or which has suffered secondary regression, hematogenic origin from an unidentified focus, or originated from intramuscular lymphoid structure.

In the described case the rapid progression of the pain, the neurological involvement and the radiologic examination suggested a neoplastic cause. However, only the histologic tests provided the diagnosis and enabled treatment.

This very unusual case reinforces the fact that backache in children and adolescents should be investigated very thoroughly.

\section{Resumo}

Os autores descrevem um caso de linfoma linfocítico pouco diferenciado, localizado na musculatura paravertebral lombar em adolescente do sexo masculino tendo lombalgia como apresentaçäo clínica inicial. 


\section{REFERENCES}

1. BRUNETON, J.N.; DROUILLARD, J.; BALU-MAESTRO, C.; LAURENT, F.; GEOFFRAY, A.; DE VERBIZIER, G.; ROGOPOULOS, A. \& BITTMANN, O. - Imagerie des lymphomes malins de topographie musculaire. J Radiol 71: 185-189, 1990.

2. BUERGER, L.F. \& MONTELEONE, P.N. - Leukemiclymphomatous infiltration of skeletal muscle. Cancer 19: 1416-1422, 1966.

3. FREEMAN, C.; BERG, J.W. \& CUTLER, S.J. - Occurrence and prognosis of extranodal lymphomas. Cancer 29: 252$260,1972$.

4. GLAZER, H.S.; LEE, J.K.T.; BALFE, D.M.; MAURO, M.A.; GRIFFITH, R. \& SAGEL, S.S. - Non-Hodgkin lymphoma: computed tomographic demonstration of unusual extranodal involvment. Radiology 149: 211-217, 1983.

5. GREM, J.L.; NEVILLE, M.B.; SMITH, S.C.; GOULD, H.R.; LOVE, R.R. \& TRUMP, D.L. - Massive skeletal muscle invasion by lymphoma. Arch Intern Med 145: 1818-1820, 1985.

6. KANDEL, R.A.; BÉDARD, Y.C.; PRITZKER, K.P.H. \& LUK, S.C. - Lymphoma presenting as an intramuscular small cell malignant tumor. Cancer 53: 1596-1589, 1984.

7. KING, H.A. - Avaliation of children with back pain. Ped Clin North Am 33: 1557-1561.
8. KING, H.A. - Back pain in children. Ped Clin North Am 31: $1084-1095,1984$.

9. KURTZBERG, J. \& GRAHAM, M.L. - Non-Hodgkin's lymphoma: biologic classification and implication of therapy. Ped Clin North Am 38: 443-456, 1991

10. MODAN, B.; SHANI, M.; GOLDMAN, B. \& MODAN, M. - Nodal and extranodal malignant lymphoma in Israel: an epidemiological study. Brit J Haematol 16: 53-59, 1969.

11. MC GURK, M.; GOEPEL, J.R. \& HANCOCK, B.W. Extranodal lymphoma of the head and neck. A review of 49 consecutive cases. Clin Radiol 36: 455-458, 1985.

12. NEWALL, J.; FRIEDMAN, M. \& NERVAEZ, F. - Extralymphonode reticulum-cell sarcoma. Radiology 91: 708712, 1968.

13. PILERI, S.; SERRA, L.; BAZZOCHI, F.; MARTINELLI, G.; GOVONI, E. \& SEVEK, B. - Linfoma maligna clinicamente primitivo del muscolo schelitrio. Pathologica 71: $485-494,1979$.

14. ROSENBLUM, B.R. \& ROTHMAN, A.S. - Low back pain in children. Mt Sinai J. Med 58: 115-120, 1991.

15. TRAVIS, W.D.; BANKS, P.M. \& REIMAN, H.M. - Primary extranodal soft tissue lymphoma of extremities. Am J Surg Pathol 11: 359-366, 1987.

16. WINTER, R.B. \& LIPSCOMB, P.R. - Back pain in children. Minn Med: 141:147-147, 1978.

17. YONG, J.L.; RIES, L.G.; SILVERBERG, E.; HORM, J.W. \& MULLER, R.W. - Cancer incidence, survival, and mortality for children younger than age 15 year. Cancer 58: 598- 602, 1986. 